in vivo $35: 1-12(2021)$

doi:10.21873/invivo.12226

Review

\title{
Suturing Skills for Medical Students: A Systematic Review
}

\author{
THANOS EMMANUEL ${ }^{1 *}$, MARIOS NICOLAIDES ${ }^{1 *}$, IAKOVOS THEODOULOU ${ }^{2}$, \\ WAI YOONG ${ }^{3}$, NIKOLAOS LYMPEROPOULOS ${ }^{4 *}$ and MICHAIL SIDERIS ${ }^{5 *}$ \\ ${ }^{1}$ Barts and The London School of Medicine and Dentistry, Queen Mary University of London, London, U.K.; \\ ${ }^{2}$ Faculty of Life Science, King's College London, London, U.K.; \\ ${ }^{3}$ North Middlesex University Hospital NHS Trust, London, U.K.; \\ ${ }^{4}$ The Royal Marsden Hospital NHS Foundation Trust, London, U.K.; \\ ${ }^{5}$ Women's Health Research Unit, Queen Mary University of London, London, U.K.
}

\begin{abstract}
Aim: This systematic review aimed to identify all published evidence on teaching suturing skills for medical students. We aimed to outline significant positive teaching outcomes and devise a comprehensive framework for the optimal teaching of suturing skills for medical students. Materials and Methods: We searched MEDLINE ${ }^{\circledR}$ (via Ovid), EMBASE and SCOPUS databases until July 2019 with no language restriction using predefined 'Population, Intervention, Comparison, Outcome (PICO)' criteria. Data were summarised in discrete thematic axes using a qualitative synthesis approach. Results: Our search yielded a total of 2,562 articles, out of which 25 were included in the final data synthesis. We provide a structured breakdown of educational interventions including participants, instructors and nature of teaching intervention. We also describe discrete means for assessment of performance and retention of suturing skills. Based on those we propose a standardised framework on teaching suturing skills for novices. Conclusion: To our knowledge this is the first systematic review investigating teaching interventions used to teach suturing skills in medical students. After extraction of individual positive teaching outcomes and utilising widely known learning theories and principles, we devised a comprehensive framework for more
\end{abstract}

This article is freely accessible online.

*Equal contribution between TE/MN and MS/NL.

Correspondence to: Michail Sideris, MD, MDRes, Ph.D., Women's Health Research Unit, Queen Mary University of London, London, United Kingdom. E-mail: msideris@nhs.net

Key Words: Suturing skills teaching, medical students, medical school, undergraduate, basic surgical skills, systematic review. efficient and cost-effective teaching of suturing skills to medical students in the future.

The acquisition of basic surgical skills (BSS) is an essential element of a doctor's professional development, ensuring safety and confidence in the clinical environment (1). The General Medical Council (GMC) requires all graduates to have proficiency in skin suturing, local anaesthetics, hand washing, surgical protective equipment and wound care (2). Paradoxically, medical degrees lack adequate BSS teaching; an example being that only $24.7 \%$ of United Kingdom medical schools incorporate suturing in their curriculum $(3,4)$. In our experience, surgical societies step up to fill this gap by organising extracurricular activities, usually with the help of local faculty. Lack of teaching, in combination with the absence of evidence-based guidelines, have led to substandard BSS performance in newly qualified doctors $(5,6)$.

Even though entry to surgical programmes remains a popular career choice, medical students are often discouraged by the intensely competitive nature of the admission process $(7,8)$. The necessity to self-organise hands-on surgical training in order to meet the bare minimum graduate requirements introduces additional barriers to an already challenging medical degree. It creates inequalities as self-organising depends on local resources, networking, and the good will of qualified surgeons. However, even after admittance into surgical programmes, novices face significant problems in skill training, including limited time, new technologies, techniques with steeper learning curves, increased patient expectations, heightened medical litigation and operating time pressures.

All the above have shaken the traditional apprenticeship training model and forced a shift towards newer teaching methods, such as simulation-based training. Introduction of simulation-based training at the undergraduate level has 
well-known benefits and can enhance surgical learning, however, it has still not been formally introduced into medical schools' surgical curricula (9). Furthermore, current teaching interventions differ in timing, instructor level, nature of delivery, and are largely based on local resources $(10,11)$. It is evident that these factors can influence quality of learning (11). Suturing has arguably the steepest learning curve amongst the required GMC surgical skills, however, there is lack of guidance on what constitutes an effective suturing course for medical students.

Hence, we performed a systematic review (SR) of the literature to identify all evidence on suturing courses for medical students, extract data on the educational interventions, outline reported teaching methods and outcomes, and devise a comprehensive standardised framework to guide future teaching of suturing skills.

\section{Materials and Methods}

Review design. This systematic review was performed according to the Preferred Reporting Items for Systematic Reviews and MetaAnalyses statement of 2009 and Assessment of Multiple Systematic Reviews' 2 validated tool $(12,13)$.

Search strategy. Electronic search of the MEDLINEâ (via Ovid), EMBASE and SCOPUS databases was carried out in July 2019. The Population, Intervention, Comparison, and Outcome (PICO) approach was used to guide development of the key word strategy. Terms such as "medical students", 'suturing course" and 'suture technique" were used. There were no limitations as to the publication date, language or level of evidence in the original searches. Additionally, we manually searched the citation lists of all included studies and relevant systematic reviews to identify any studies not captured in the original search. Results were exported to a reference manager (EndNote X9.1 for Mac; Clarivate Analytics, London, UK) for duplicate removal and screening.

Eligibility criteria and screening. All non-duplicate articles were screened following a two-step process: Title/abstract and full-text screening by two independent reviewers (T.E. and M.N.). Screening at both stages was performed against pre-defined inclusion and exclusion criteria, guided by the PICO approach. Inclusion criteria limited studies to only those evaluating teaching interventions involving suturing skill acquisition (intervention) and involving undergraduate medical students as subjects (population). The evaluation should have been based on measurement of subjective or objective change in skill acquisition (outcome) following teaching intervention (pre-/post- change comparison) or compared to no intervention (control). Qualitative studies solely reporting student or faculty perceptions on teaching interventions were excluded. Any conflict between reviewers during title/abstract screening process was resolved by including the study by default, whereas conflicts during full-text screening were resolved by senior author (M.S.) consensus.

Data extraction and synthesis. Data extraction was carried out by two independent reviewers (T.N and M.N) using a digital spreadsheet with pre-defined extraction fields structured around the
Table I. Extraction fields using population, intervention, comparison and outcome criteria.

\begin{tabular}{ll}
\hline Category & Extraction fields \\
\hline Population & $\begin{array}{l}\text { Number of undergraduate medical students } \\
\text { Previous suturing experience } \\
\text { Year of study }\end{array}$ \\
Intervention/Control & $\begin{array}{l}\text { Intervention type } \\
\text { Duration of course } \\
\text { Instructor staff level }\end{array}$ \\
& Equipment used \\
Outcome & Performance \\
& Retention of skill \\
& Self-confidence \\
\hline
\end{tabular}

PICO framework shown in Table I. Any discrepancies in data were identified and resolved in scheduled meetings.

Data on the population included the total number of medical students recruited, their year of study and any previous experience in suturing skills. Intervention types were standardised to instructor versus self-directed training. Instructor-directed teaching interventions were guided by healthcare professionals or nonclinical tutors. Self-directed interventions did not involve an instructor during the teaching phase of the intervention. Studies combining both types were reported as 'Instructor-directed training with home-practice'. The nature of the teaching intervention was also explored by identifying the type of didactic material and level of the instructors used. Type of didactic material included video presentations, lectures, textbooks and images. Equipment used for training involved either 'dry' or 'wet' simulation models. Hardwarebased, synthetic simulators were considered 'dry' models, whereas animal-tissue models were considered 'wet'. The duration of each teaching intervention was also documented.

Finally, we explored the methods used to assess the outcome. Methods of assessment consisted of both objective and subjective assessment tools. Objectively, studies assessed skill acquisition using standardised validated or non-validated assessment tools that minimised bias. Subjective methods included self-assessment questionnaires of student performance or confidence using scales such as Likert scales. Outcomes were regarded and reported as 'positive outcomes' when a statistically significant improvement in suturing performance was shown upon assessment.

\section{Results}

Initially, we identified a total of 2,562 articles, out of which 25 were included in the final data synthesis as shown in Figure 1. We excluded studies for reasons such as recruitment of nonundergraduate trainees, lack of measurement of skill acquittance either in comparison to a control or to preintervention base performance, and evaluation of skills other than suturing. The main characteristics of all included studies are outlined in Table II. Fourteen studies were randomised controlled trials, six quasi-experimental and five observational. The majority (16 out of 25 ) were carried out in the past 10 years. Ten studies were carried out in the USA, five in Canada 


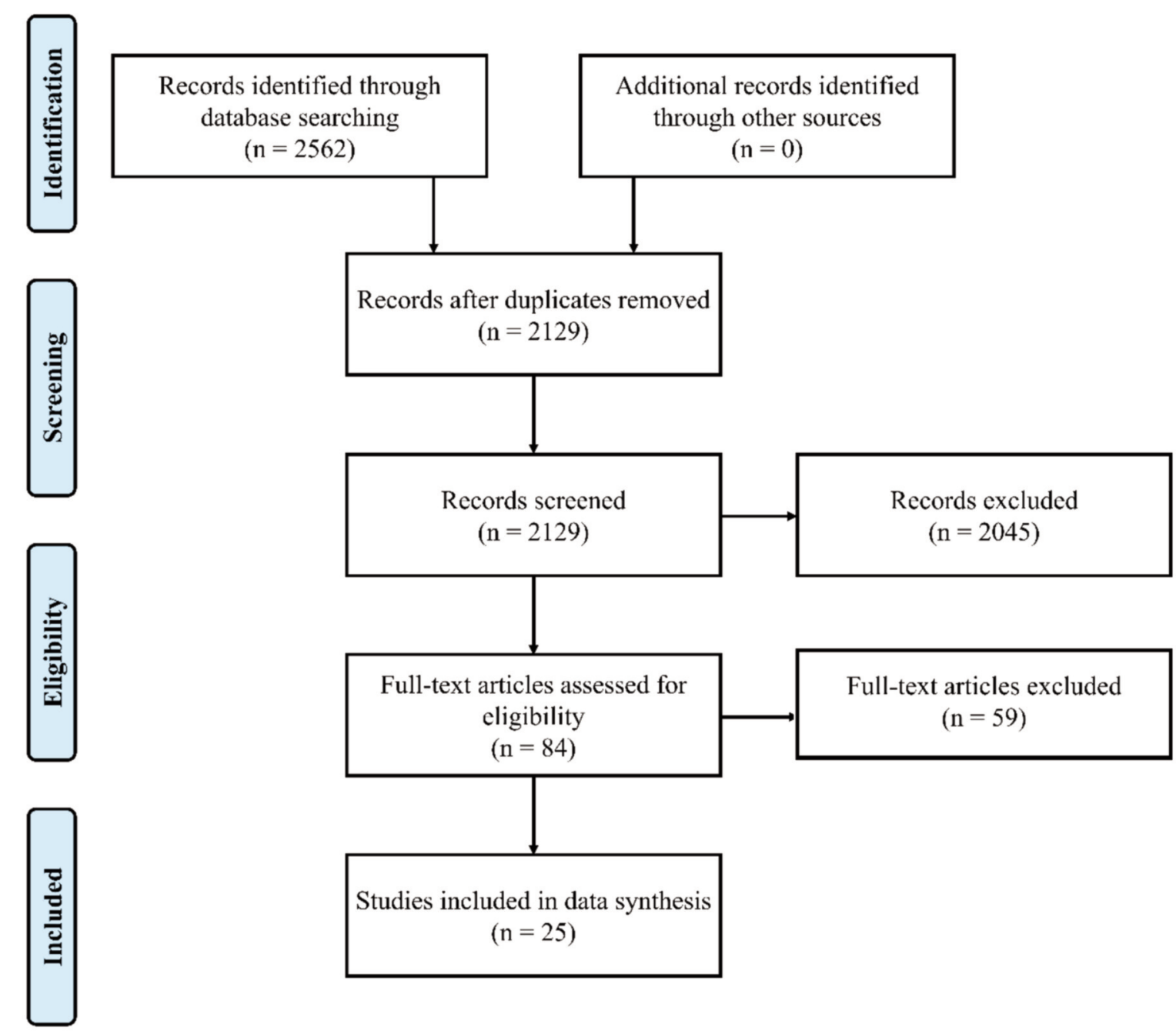

Figure 1. PRISMA flowchart.

and three in Brazil, whereas only three studies were carried out in Europe, two in Asia, one in Africa and one in Australia. Great variability was noted in the number of participants recruited, ranging from nine to 108 . Most studies recruited on a voluntary basis. Four out of the 25 studies reported that students had no previous suturing skills experience (14-17). Most teaching interventions (18 out of 25), targeted medical students in their pre-clinical years.

Educational intervention. We identified 13 studies using instructor-directed teaching, seven self-directed training and five using a combination of both (Table II). Noteworthily, all seven self-directed studies had positive outcomes (16, 18-24). A common feature of all studies was the initial use of didactic material and presentation of the correct suturing technique, followed by hands-on practical training. The most common didactic material used was video demonstration $(n=18)$, followed by lectures $(n=7)$, live demonstration $(n=5)$, images $(n=2)$ and textbooks $(n=1)$ (Table III). Video-based instructions were used both in self-directed and instructor-guided teaching interventions. Hands-on training formed the basis of all teaching interventions of the studies included in our SR.

Hands-on training implemented either 'dry' $(n=22)$ or 'wet' models $(n=2)$, while one study compared the two models (25). All three 'wet' models utilising live tissue used porcine models. One study encouraged active participation of students in the operating theatre after exposure and training on a porcine model (26). All studies regardless of using 'dry' or 'wet' models demonstrated positive results.

The duration of the teaching intervention, including both didactic material and hands-on training, ranged from 10 minutes to 12 weeks (Table III). One study did not predefine the intervention duration, as participants were instructed to pace their own learning (23). 
Table II. Demographics of included studies.

\begin{tabular}{|c|c|c|c|c|c|}
\hline Author, year (Ref) & Region & $\begin{array}{l}\text { Intervention } \\
\text { type }\end{array}$ & $\begin{array}{l}\text { Intervention } \\
\text { duration }\end{array}$ & $\begin{array}{l}\text { Number of } \\
\text { participants }\end{array}$ & Study type \\
\hline Routt et al. (14) & USA & Instructor-directed & 30 Days & $\mathrm{n} / \mathrm{a}$ & Randomised controlled study \\
\hline Wongietka et al. (15) & Thailand & Instructor-directed & 10 Weeks & 81 & Randomised controlled study \\
\hline O'Connor et al. (16) & Canada & Self-directed & 5 Hours & 14 & Quasi experimental \\
\hline Porte et al. (17) & Canada & Self-directed & 1 Day & 45 & Quasi experimental \\
\hline Brydges et al. (18) & USA & Self-directed & 1 Week & 48 & Quasi experimental \\
\hline Xeroulis et al. (19) & Canada & $\begin{array}{l}\text { Self-directed } v s \text {. } \\
\text { instructor-directed }\end{array}$ & 1 hour & 60 & Randomised controlled study \\
\hline Summer et al. (20) & USA & Self-directed & 7 Hours & 69 & Randomised controlled study \\
\hline Ganier and de Vries (21) & France & Self-directed teaching & 1 Week & 48 & Quasi experimental \\
\hline Nousiainen et al. (22) & Canada & Self-directed & 40 Minutes & 24 & Quasi experimental \\
\hline Wright et al. (23) & USA & Self-directed & Self-guided pace & 9 & Quasi experimental \\
\hline Pender et al. (24) & USA & $\begin{array}{l}\text { Instructor-directed with } \\
\text { home practice }\end{array}$ & 12 Weeks & 65 & Observational study \\
\hline Denadai et al. (25) & Brazil & Instructor-directed & 1 Hour & 36 & Randomised controlled study \\
\hline Bauer et al. (26) & Germany & Instructor-directed & 9 Weeks & 20 & Randomised controlled study \\
\hline Bennet et al. (27) & UK & Instructor-directed & 5 Days & 70 & Observational study \\
\hline Denadai et al. (28) & Brazil & Instructor-directed & 1 Hour & 48 & Randomised controlled study \\
\hline Kim et al. (29) & USA & Instructor-directed & 2 Hours & 49 & Randomised controlled study \\
\hline Denadai et al. (30) & Brazil & Instructor-directed & 1 Hour & 16 & Randomised controlled study \\
\hline Dubrowski and MacRae (31) & USA & Instructor-directed & 1 Hour & 108 & Randomised controlled study \\
\hline Yap et al. (32) & Australia & Instructor-directed & 90 Minutes & 23 & Randomised controlled study \\
\hline Brunt et al. (35) & USA & $\begin{array}{l}\text { Instructor-directed with } \\
\text { home-practice }\end{array}$ & 7 Weeks & 20 & Observational study \\
\hline Alameddine et al. (36) & USA & Instructor-directed & 10 Minutes & 16 & Randomised controlled study \\
\hline Bekele et al. (37) & Ethiopia & Instructor-directed & 1 Week & 44 & Randomized controlled study \\
\hline Gershuni et al. (38) & USA & $\begin{array}{l}\text { Instructor-directed with } \\
\text { home practice }\end{array}$ & 8 Weeks & 21 & Randomised controlled study \\
\hline Kyle et al. (51) & Canada & Instructor-directed & 1.5 Hours & 61 & Observational study \\
\hline Seo et al. (56) & Korea & Instructor-directed & 1 Day & 91 & Observational study \\
\hline
\end{tabular}

Seven studies reported the use of surgeons as instructors, whereas two studies used surgical residents and five used physicians. In addition, three studies compared instructors of different medical background: foundation-year doctors against medical students (27), final year medical students against qualified surgeons (28), and non-physicians against qualified surgeons (29). In addition, one study compared physician-guided training against self-directed learning (19) (Table III). Six studies reported the number of instructors used and all of them utilised an instructor to participant ratio of $1: 4(25,27,28,30-32)$.

Performance and retention of suturing skills. To test the efficacy of teaching interventions, all studies measured the suturing performance before (baseline) and after the course, with or without comparison to a control group. We summarised the assessment method used by each study in Table III. The most common objective method used to measure performance was the Objective Structured Assessment of Technical Skill (OSATS) tool (33). Other methods of assessment included the total time taken to complete a suture, hand-motion analysis using the Imperial College Surgical Assessment Device, Objective Structured Clinical Examination, Final Product Analysis and absolute symmetry error (34). Some studies developed their own set of criteria and measured performance using a Likert Scale $(15,24)$. Subjective assessments were also used by several studies, either to assess confidence $(27,35)$ or performance $(23,26,36)$. The prevalence of all types of evaluative metrics used to measure the study outcomes are shown in Figure 2.

Only eight studies investigated the retention of skill acquisition after an extended time period (14, 17-19, 22, 31, 37,38 ). Half of the studies concluded that there was decay in the skills of students after the end of the teaching intervention $(14,17,18,37)$. Four studies evaluated skill retention at 30 days $(14,17,19,22)$ and two at 7 days $(18,31)$. Two studies evaluated skill retention over an extended time period from 7 months in one to a year later in the other $(37,38)$.

Synoptic analysis. Analysing the included studies and data extracted from the breakdown of the teaching interventions as shown in Table III, we deduced several significant 


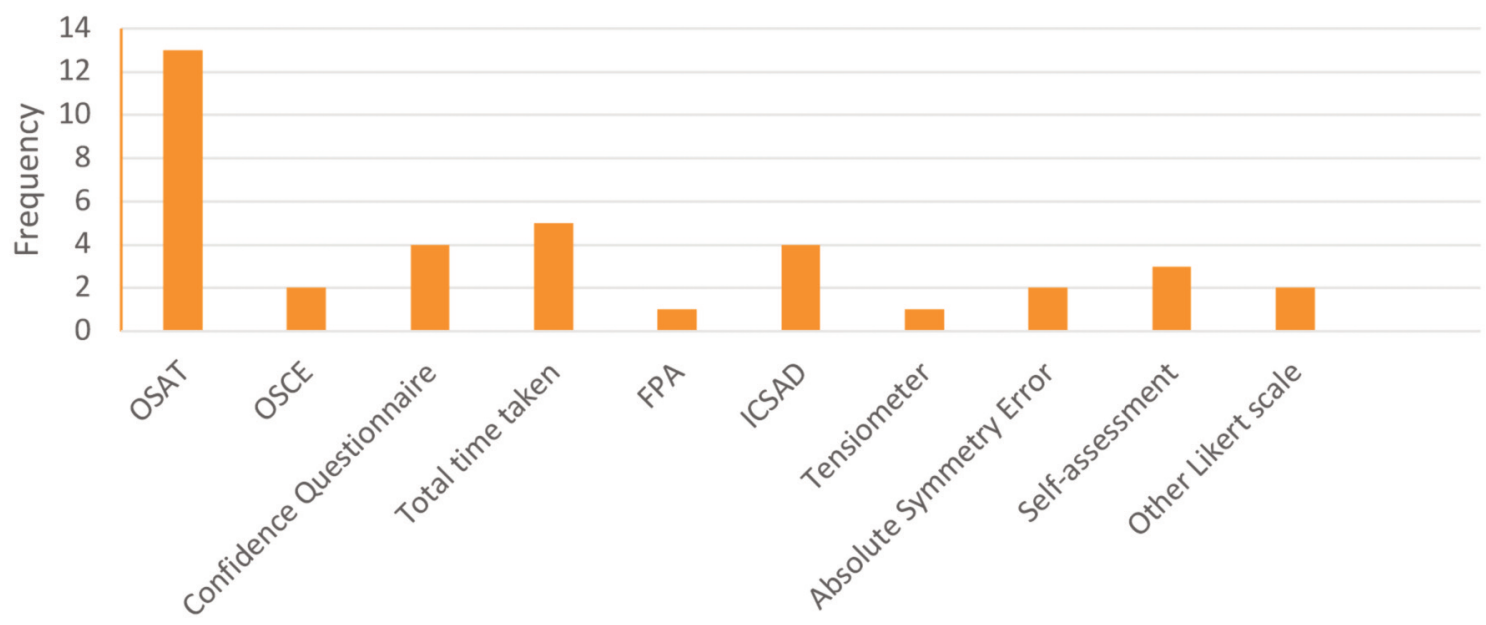

Assessment of performance

Figure 2. Prevalence of evaluative metrics used to measure teaching intervention outcome in the included studies. ICSAD: Imperial College Surgical Assessment Device; OSAT: Objective Structured Assessment of Technical Skills; OSCE: Objective Structured Clinical Examination; FPA: Final Product Analysis.

outcomes. Synoptically, Denadai et al. compared a lowfidelity suture training model (synthetic ethylene-vinyl acetate bench model) against a high-fidelity suture training model (pig feet skin bench model) and reported that there was no difference in skill acquisition (25). Furthermore, several studies compared computer-based video interventions to instructor-guided interventions, and found the two intervention types to be equally effective $(16,19,20,22)$. Following the teaching period when assessing retention of taught skills, O'Connor et al. demonstrated that distributed suturing practice over a lengthier period of time was more effective and led to greater skill retention than single instructional sessions (16). Interestingly, studies comparing expert instructors, such as surgeons and physicians to nonphysician coaches, showed that skill acquisition was similar irrespective of the instructor level (27-29). In particular, medical student tutoring was shown to be an effective and feasible method for teaching surgical skills (27). In addition to this, further studies using senior medical students for peerto-peer tutoring and re-demonstration of learned suturing techniques to more novice students, resulted in further improvement of suturing skills both in senior and novice medical students $(15,32)$. As a result, this allows the mass provision of surgical skills courses using students as instructors. Consequently, the optimal student to instructor ratio as demonstrated by Dubrowski and Macrae, of one instructor to four students, can be achieved in a more feasible and cost-effective way using medical students as tutors (31).

Framework. After the collection and thorough analysis of the data derived from each of the teaching interventions included in our SR, we combined the main positive outcomes and referred to learning theories as outlined by Fitts and Posner (39) and Gagne (40). Furthermore, using these learning principles and implementing the important outcomes of the studies included in this SR, we developed a framework for future suturing courses. Figure 3 summarises our recommendations in a simple yet comprehensive framework that aims to standardise teaching of suturing skills for medical students.

\section{Discussion}

Suturing is one of the fundamental skills the GMC expects graduating doctors to possess. Nevertheless, it is one of the most challenging skills to acquire and gain proficiency in. We identified all published literature on suturing courses for medical students, evaluated the differences between the different types of teaching interventions and synthesised the evidence to devise a standardised framework to guide future teaching of suturing skills.

The increasing number of studies published in the past decade reflects the increasing interest in research on effective teaching interventions and is in line with the emergence of simulation-based teaching interventions. This is especially important given the decreasing duration of surgical rotations and limited time for training in clinical environments. Evidently, all studies of our SR used laboratory-based settings for teaching. We therefore support the shift of technical skills teaching from the operating room to a laboratory simulation-based setting.

Upon systematically drawing information from the included articles, we identified differences in parameters, 
in vivo $35: 1-12$ (2021)

Table III. Summary of teaching interventions, equipment, method of performance assessment and outcome of the studies.

\begin{tabular}{|c|c|c|c|c|c|c|}
\hline $\begin{array}{l}\text { Author, } \\
\text { year (Ref) }\end{array}$ & $\begin{array}{l}\text { Nature of teaching } \\
\text { intervention studied }\end{array}$ & Staff level & $\begin{array}{l}\text { Student year } \\
\text { of study }\end{array}$ & $\begin{array}{l}\text { Model } \\
\text { used }\end{array}$ & $\begin{array}{l}\text { Assessment } \\
\text { method }\end{array}$ & Results \\
\hline $\begin{array}{l}\text { Routt } \\
\text { et al. (14) }\end{array}$ & $\begin{array}{l}\text { Video demonstration, live } \\
\text { demonstration and hands-on } \\
\text { training with active feedback }\end{array}$ & Physicians & $\begin{array}{c}1^{\text {st }-2 \text { nd }} \text { Year } \\
\text { (no previous suturing } \\
\text { experience) }\end{array}$ & Dry & OSATS & $\begin{array}{l}\text { Positive (decay } \\
\text { with time) }\end{array}$ \\
\hline $\begin{array}{l}\text { Wongietka } \\
\text { et al. (15) }\end{array}$ & $\begin{array}{c}\text { Live demonstration and } \\
\text { hands-on training augmented } \\
\text { with home-practice and } \\
\text { peer-peer redemonstrations }\end{array}$ & Physicians & $\begin{array}{c}1^{\text {st }} 3^{\text {rd }} \text { Year } \\
\text { (no previous suturing } \\
\text { experience) }\end{array}$ & Dry & $\begin{array}{l}\text { Performance } \\
\text { assessment } \\
\text { (Likert scale) }\end{array}$ & Positive \\
\hline $\begin{array}{l}\text { O'Connor } \\
\text { et al. }(16)\end{array}$ & CBVI and hands-on practice & Self-directed & $\begin{array}{c}1^{\text {st }} \text { Year } \\
\text { (no previous suturing } \\
\text { experience) }\end{array}$ & Dry & OSCE & Positive \\
\hline $\begin{array}{l}\text { Porte et al. } \\
\text { (17) }\end{array}$ & $\begin{array}{l}\text { Video demonstration and } \\
\text { hands-on training with } \\
\text { active feedback }\end{array}$ & Surgeon & $\begin{array}{c}1^{\text {st }} \text { Year } \\
\text { (no previous suturing } \\
\text { experience) }\end{array}$ & Dry & $\begin{array}{c}\text { OSATS } \\
\text { and ICSAD }\end{array}$ & Positive \\
\hline $\begin{array}{l}\text { Brydges } \\
\text { et al. (18) }\end{array}$ & $\begin{array}{l}\text { Video demonstration and } \\
\text { hands-on training }\end{array}$ & Self-directed & Undergraduate & Dry & $\begin{array}{l}\text { FPA and Absolute } \\
\text { Symmetry Error }\end{array}$ & Positive \\
\hline $\begin{array}{l}\text { Xeroulis } \\
\text { et al. (19) }\end{array}$ & $\begin{array}{l}\text { CBVI vs. physician feedback } \\
\text { and hands-on training }\end{array}$ & $\begin{array}{l}\text { Self-directed } \\
\text { vs. Physician }\end{array}$ & $1^{\text {st }}$ Year & Dry & $\begin{array}{c}\text { OSATS } \\
\text { and ICSAD }\end{array}$ & $\begin{array}{l}\text { Positive } \\
\text { in both }\end{array}$ \\
\hline $\begin{array}{l}\text { Summer } \\
\text { et al. }(20)\end{array}$ & CBVI and home-practice & Self-directed & $1^{\text {st }}$ Year & Wet & OSATS & Positive \\
\hline $\begin{array}{l}\text { Ganier and } \\
\text { de Vries (21) }\end{array}$ & $\begin{array}{l}\text { Text, Images or Video } \\
\text { demonstration and } \\
\text { hands-on training }\end{array}$ & Self-directed & $2^{\text {nd }}$ Year & Dry & $\begin{array}{l}\text { OSATS and Total } \\
\text { Time Taken }\end{array}$ & Positive \\
\hline $\begin{array}{l}\text { Nousiainen } \\
\text { et al. }(22)\end{array}$ & $\begin{array}{l}\text { CBVI and hands-on } \\
\text { practice }\end{array}$ & Self-directed & $1^{\text {st }} 2^{\text {nd }}$ Year & Dry & ICSAD & Positive \\
\hline $\begin{array}{l}\text { Wright } \\
\text { et al. }(23)\end{array}$ & CBVI and home-practice & Self-directed & $1^{\text {st }}-2^{\text {nd }}$ Year & Dry & $\begin{array}{l}\text { Self-assessment } \\
\text { and OSATS }\end{array}$ & Positive \\
\hline $\begin{array}{l}\text { Pender } \\
\text { et al. }(24)\end{array}$ & $\begin{array}{c}\text { Video and live } \\
\text { demonstration and } \\
\text { home practice }\end{array}$ & Self-directed & $3^{\text {rd }}$ Year & Dry & $\begin{array}{l}\text { Self-assessment } \\
\text { (Likert scale), and } \\
\text { confidence } \\
\text { questionnaire } \\
\text { assessment }\end{array}$ & Positive \\
\hline $\begin{array}{l}\text { Denadai } \\
\text { et al. }(25)\end{array}$ & $\begin{array}{l}\text { Video demonstration and } \\
\text { hands-on training with } \\
\text { active feedback }\end{array}$ & Surgeons & Undergraduate & $\begin{array}{c}\text { Dry } \\
v s . \text { wet }\end{array}$ & $\begin{array}{l}\text { OSAT, and } \\
\text { confidence } \\
\text { questionnaire } \\
\text { assessment }\end{array}$ & $\begin{array}{l}\text { Positive (both } \\
\text { 'dry' and 'wet' } \\
\text { models) }\end{array}$ \\
\hline $\begin{array}{l}\text { Bauer } \\
\text { et al. (26) }\end{array}$ & $\begin{array}{l}\text { Video demonstration and } \\
\text { hands-on training with } \\
\text { active feedback }\end{array}$ & Surgeons & $3^{\text {rd }}-5^{\text {th }}$ Year & Wet & $\begin{array}{l}\text { OSCE and } \\
\text { Self-assessment } \\
\text { (Likert scale) }\end{array}$ & Positive \\
\hline $\begin{array}{l}\text { Bennet } \\
\text { et al. (27) }\end{array}$ & $\begin{array}{l}\text { Video demonstration and } \\
\text { hands-on training with } \\
\text { active feedback }\end{array}$ & $\begin{array}{l}\text { Foundation } \\
\text { year doctors } v s \text {. } \\
\text { medical students }\end{array}$ & Undergraduate & Dry & $\begin{array}{l}\text { Confidence } \\
\text { questionnaire } \\
\text { assessment }\end{array}$ & $\begin{array}{l}\text { Positive } \\
\text { in both }\end{array}$ \\
\hline $\begin{array}{l}\text { Denadai } \\
\text { et al. }(28)\end{array}$ & $\begin{array}{l}\text { Video demonstration and } \\
\text { hands-on training with } \\
\text { active feedback }\end{array}$ & $\begin{array}{c}\text { Final year } \\
\text { medical students } \\
\text { vs. surgeons }\end{array}$ & $1^{\text {st }} 2^{\text {nd }}$ Year & Dry & $\begin{array}{l}\text { OSATS, and } \\
\text { confidence } \\
\text { questionnaire } \\
\text { assessment }\end{array}$ & $\begin{array}{l}\text { Positive in both } \\
\text { student and } \\
\text { surgeon-directed } \\
\text { teaching }\end{array}$ \\
\hline $\begin{array}{l}\text { Kim } \\
\text { et al. (29) }\end{array}$ & $\begin{array}{l}\text { Hands-on training } \\
\text { with surgeon } v s \text {. } \\
\text { non-physician } \\
\text { skills coach }\end{array}$ & $\begin{array}{l}\text { Surgeon } v s \text {. } \\
\text { Non-physician } \\
\text { skills coach }\end{array}$ & $3^{\text {rd }}-4^{\text {th }}$ Year & Dry & $\begin{array}{l}\text { Total time taken, } \\
\text { and performance } \\
\text { assessment } \\
\text { (Likert scale) }\end{array}$ & Positive in both \\
\hline $\begin{array}{l}\text { Denadai } \\
\text { et al. }(30)\end{array}$ & $\begin{array}{l}\text { Video demonstration } \\
\text { and hands-on training } \\
\text { with active feedback }\end{array}$ & Surgeons & $2^{\text {nd }}$ Year & Dry & OSAT & Positive \\
\hline $\begin{array}{l}\text { Dubrowski } \\
\text { and MacRae. } \\
\text { (31) }\end{array}$ & $\begin{array}{l}\text { Live demonstration and } \\
\text { hands-on training with } \\
\text { active feedback } \\
(1: 2,1: 4,1: 12)\end{array}$ & $\begin{array}{l}\text { Surgical } \\
\text { residents }\end{array}$ & $1^{\text {st }} 2^{\text {nd }}$ Year & Dry & $\begin{array}{c}\text { ICSAD } \\
\text { assessment, total } \\
\text { time taken, and } \\
\text { number of hand } \\
\text { movements }\end{array}$ & Positive \\
\hline
\end{tabular}


Table III. Continued

\begin{tabular}{|c|c|c|c|c|c|c|}
\hline $\begin{array}{l}\text { Author, } \\
\text { year (Ref) }\end{array}$ & $\begin{array}{l}\text { Nature of teaching } \\
\text { intervention studied }\end{array}$ & Staff level & $\begin{array}{l}\text { Student year } \\
\text { of study }\end{array}$ & $\begin{array}{c}\text { Model } \\
\text { used }\end{array}$ & $\begin{array}{l}\text { Assessment } \\
\text { method }\end{array}$ & Results \\
\hline $\begin{array}{l}\text { Yap } \\
\text { et al. (32) }\end{array}$ & $\begin{array}{l}\text { Live demonstration } \\
\text { and hands-on training with } \\
\text { peer-peer redemonstrations }\end{array}$ & Physicians & $1^{\text {st }}$ Year & Dry & OSATS & Positive \\
\hline $\begin{array}{l}\text { Brunt } \\
\text { et al. (35) }\end{array}$ & $\begin{array}{l}\text { Video demonstration and } \\
\text { hands-on training with } \\
\text { active feedback }\end{array}$ & Surgeons & $4^{\text {th }}$ Year & Dry & $\begin{array}{c}\text { Confidence } \\
\text { questionnaire assessment, } \\
\text { and total time taken }\end{array}$ & Positive \\
\hline $\begin{array}{l}\text { Alameddine } \\
\text { et al. }(36)\end{array}$ & $\begin{array}{l}\text { Hands-on training } \\
\text { with active feedback }\end{array}$ & Physicians & $4^{\text {th }}$ year & Dry & $\begin{array}{l}\text { Self and expert } \\
\text { assessment } \\
\text { (Likert scale) }\end{array}$ & Positive \\
\hline $\begin{array}{l}\text { Bekele } \\
\text { et al. (37) }\end{array}$ & $\begin{array}{l}\text { Video demonstration } \\
\text { and hands-on training }\end{array}$ & Surgeons & $5^{\text {th }}$ Year & Dry & OSATS & $\begin{array}{l}\text { Positive (decay } \\
\text { with time) }\end{array}$ \\
\hline $\begin{array}{l}\text { Gershuni } \\
\text { et al. (38) }\end{array}$ & $\begin{array}{l}\text { Lecture and hands-on } \\
\text { training with retrospective } \\
\text { feedback after home-practice }\end{array}$ & Surgeons & $4^{\text {th }}$ Year & Dry & $\begin{array}{l}\text { OSATS, and } \\
\text { total time taken }\end{array}$ & Positive \\
\hline $\begin{array}{l}\text { Kyle } \\
\text { et al. (51) }\end{array}$ & $\begin{array}{l}\text { Live demonstration and } \\
\text { hands-on training }\end{array}$ & $\begin{array}{l}\text { Surgical } \\
\text { residents }\end{array}$ & $1^{\text {st }}-2^{\text {nd }}$ Year & Dry & $\begin{array}{l}\text { Tensiometer, } \\
\text { and OSATS }\end{array}$ & Positive \\
\hline $\begin{array}{l}\text { Seo } \\
\text { et al. (57) }\end{array}$ & $\begin{array}{l}\text { Lecture and video } \\
\text { demonstration and hands-on } \\
\text { training with active feedback }\end{array}$ & Physicians & $1^{\text {st }} 4^{\text {th }}$ Year & Dry & OSATS & Positive \\
\hline
\end{tabular}

CBVI: Computer-based video intervention; OSATS: Objective Structured Assessment of Technical Skills; FPA: final product analysis; ICSAD: Imperial College Surgical Assessment Device; OSCE: objective structured clinical examination.

such as the nature of the teaching intervention, the equipment and the level and number of instructors. Quantitative comparison and analyses were not possible as we were unable to adjust for all variable parameters. Thus, we aimed to identify positive outcomes of individual studies and synoptically synthesise the evidence to devise a standardised and effective framework guiding future teaching of suturing skills in medical students.

Equipment. Synthetic 'dry' bench models are cost-effective, readily available and portable (41-43). Evidently, they are effective in the acquisition, retention and transferability of suturing skills to a clinical setting $(42,44,45)$. 'Dry' models were predominantly used in the studies of this SR and all yielded a positive improvement in suturing skills (Table III). On the other hand, the use of 'wet' models was only observed in three studies showing equally promising results. However, this type of equipment is associated with greater costs and reduced availability. Both 'dry' and 'wet' models were found to be equally effective in suturing skill acquisition (25). Given the advantages of 'dry' models and the findings of this SR, future suturing courses should not hesitate to use either 'dry' or 'wet' equipment, based on local availability of resources.

Student participants. As indicated in Table III, pre-clinical students were the predominant group of students recruited. Involving students during the first years of medical school allows early exposure and acquisition of basic surgical skills. On the other hand, teaching suturing for students in clinical years can go hand in hand with hospital exposure. Both categories of studies have demonstrated positive findings, hence suturing teaching is beneficial at any time point in medical school. Nevertheless, it is important to encourage distributed practice of suturing skills especially for students taught early during non-clinical years in order to maintain skill level and ensure proficiency at the time of graduation.

Instructors. Availability of time remains an important issue for faculty surgeons who struggle to set aside their clinical roles for the education and training of medical students (46, 47). On assessment of the included studies, we found that an effective alternative is the use of non-expert instructors (27$29,32)$. It has been demonstrated that teaching of suturing skills by senior medical students can have equally beneficial effects as teaching by expert surgeons $(27,28)$. Peer-assisted learning is widely accepted as an effective teaching method with numerous advantages over traditional techniques $(14,15$, 32). This approach not only allows novice medical students to develop their skills in a non-intimidating environment, but also offers senior medical students an opportunity to further enhance their technical and teaching skills. Although peerassisted learning has been shown to be beneficial when teaching basic surgical skills to novice medical students, caution is needed when extrapolating results to more complex procedures and experienced trainees $(28,29)$. 


\section{Prerequisite}

\section{knowledge Didactic material}

- Supplementary lectures providing information on suturing instruments and theoretical knowledge.

- Testing of prerequisite knowledge using SBA before progressing to next stage.

- Inform learners of the objectives and familiarise with method of assessment including checklist requirement.

- Video-demonstrations of suturing technique used as a first-line intervention. Students should be given online access to the didactic material and be able to replay video.

\section{Eliciting}

\section{performance Hands on training on dry bench model}

- Practice trials on simulator bench model before feedback and correction by instructors.

- Instructors can include senior medical students trained in suturing skills hence supporting the PAL approach at an instructor to student ratio of 1:4.

- Sessions distributed over lengthier period instead of a single mass instructional session.

- Assess students with predetermined proficiency standards using objective tools such as the OSAT.

\section{Maintaining}

\section{proficiency Retention of skills}

- Recruitment of students during early pre-clinical years and incorporation of sessions in undergraduate medical curriculum for at least 10 weeks.

- Intermittent evaluation of performance to ensure proficiency is maintained.

- Providing students with home practice kit and prompting independent practice at regular intervals.

- Encourage students to revisit online didactic material including video presentations to aid memorisation.

- Peer-to-peer teaching and opportunity to teach more novice students later on course hence maintaining the PAL cycle.

Figure 3. Framework guiding a standardised teaching approach for suturing skills in novice medical students. OSAT: Objective Structured Assessment of Technical Skill; PAL: peer-assisted learning; SBA: single best answer.

One study included in our review investigated the optimal instructor to student ratio and concluded that the optimal ratio is one instructor to four students (31). This ratio has been widely accepted, aiming to maximise student learning. Although beneficial, this ratio imposes great demand on expert instructors, who are not always available for teaching practical skills.

Nature of teaching intervention. An important variable we identified between the studies was the type of didactic material used to convey the suturing technique to students. We deduced that studies mostly used video demonstrations either as part of a self-directed intervention or in combination with instructor-guided teaching. We found significantly positive results in studies using video demonstrations as part of self-directed interventions, with improvements seen in both self-assessed and expert-assessed performance (20, 23). Video-based instructions have been shown to have a significant role in procedural learning (48-50) and motor 
skills (21). Evidently, the included studies demonstrated no significant differences between computer-based video and expert instructor-directed interventions $(19,22)$. This can be explained by the fact that novice inexperienced medical students, can attain sufficient information from instructional videos alone to improve their basic performance. We therefore suggest the use of videos both as an introduction to the skill and as a visual aid during and after the learning process. This strategy allows more efficient use of the time spent with tutors as described by the first stage of Fitts and Posner's 3-stage learning theory (39). Finally, the flexibility and self-directed nature of this intervention can dramatically reduce the strain on overstretched healthcare systems, especially during times of crisis such as the current COVID19 pandemic. We speculate that self-directed teaching strategies will gain increasing attention in the near future.

Performance assessment. Given the large number of medical students attending basic surgical courses and the limited number and time of faculty instructors, it is imperative to find a standardised assessment tool that is cheap, valid, reliable but not labour-intensive. A widely used standardised assessment tool will also allow comparison and meta-analysis of future studies. Although some studies have investigated the use of non-expert objective methods to assess improvements in quality of knots such as tensiometry, current evidence suggests that expert-based assessment of student performance is imperative (51). The most common expert-based assessment tool used in our included studies was the OSATS tool. We encourage more widespread use of the OSATS tool to allow more direct and quantitative comparisons of teaching interventions in future studies. As shown in Table III, several studies provided a self-assessment scale allowing learners to measure their own progress. Self-assessment and expert assessment tools have been validated, with good correlation between the two scales (52).

Skill retention. We found there was a great paucity of data on retention of skills following teaching interventions; evidently only eight of the 25 studies included in our SR investigated retention of taught skills. Paradoxically, evidence shows that skill decay begins from day 1 after the intervention (53-55). Moreover, from the studies investigating skill decay in our SR, four concluded that there was decay in the skills of students after the end of the teaching intervention $(14,17,18,37)$. One of these studies concluded that although single instructional sessions improved suturing performance in the short-term (56), they were not sufficient to maintain suturing proficiency over longer periods of time (14). This is important as training of medical students aims to improve basic surgical skill acquisition and proficiency to ensure students are competent when they qualify. It is evident that retention is significantly better when teaching and practice is distributed over an extended time period compared to single instructional mass sessions (37). Retention of skills is further enhanced by independent home practice with intermittent evaluation (14). Future teaching interventions should encourage independent practice after the end of the course. We therefore recommend the use of home-practice suturing kits to prevent performance deterioration $(26,57)$.

Interestingly, the use of computer-based video interventions was found to lead to improved retention of suturing skills $(14,19,20)$. This can be explained by students being able to replay videos in slow-motion and repeatedly watch throughout the technique at a later stage, which aids in memorisation and retention. Evidently, Xeroulis et al. showed that computer-based video intervention improved retention when compared to expert feedback during practice trials (19). We therefore suggest the incorporation of computer-based video intervention in addition to distributed practice sessions and independent home practice in order to achieve maximal acquisition and retention of skills.

Standardised framework for teaching suturing skills in medical students. After extracting, synthesising and analysing the evidence from all included studies, we identified and summarised significant findings. These were used in combination with widely accepted learning theories to develop a standardised framework for systematically guiding educators on the optimal approach for teaching suturing skills to medical students. None of the suggestions are difficult or time-consuming to implement yet their introduction may prove beneficial. We therefore aim to minimise future unstructured and opportunistic teaching. We speculate that these principles are readily transferrable to other surgical skills. Nevertheless, we do appreciate that application of the described framework will not be possible at all institutions, mainly because of variations in resource availability and local demands. Furthermore, the suggested framework was devised largely based on the captured literature, thus, conclusions cannot be definite. However, this framework can encourage standardisation of future courses to allow consequent comparison of outcomes.

\section{Conclusion}

To our knowledge, this is the first SR exploring teaching courses for suturing skills in medical students. We identified several variable factors in educational approaches to suturing skills. After acknowledging each of these factors, we identified all positive outcomes. Upon synthesising the evidence, we devised a simple, yet comprehensive framework aiming for a more efficient and cost-effective approach when teaching suturing skills to medical students. 
The findings of this review are of value to individuals, organisations or institutions interested in teaching of basic surgical skills such as suturing to medical students.

\section{Conflicts of Interest}

The Authors declare that they have no conflicts of interest in regard to this study.

\section{Authors' Contributions}

Michail Sideris conceived research question and methodology with Marios Nicolaides and they edited final version. Thanos Emmanuel and Marios Nicolaides are equal contributors who screened literature and drafted the article. Iacovos Theodoulou contributed in drafting parts of the article and editing the final version. Nikolaos Lymperopoulos and Wai Yoong offered senior editing and contributed to the final version of this article. All Authors approved final version of the article.

\section{References}

1 Chipman JG, Acton RD and Schmitz CC: Developing surgical skills curricula: Lessons learned from needs assessment to program evaluation. J Surg Educ 66(3): 133-139, 2009. PMID: 19712911. DOI: $10.1016 /$ j.jsurg.2009.03.032

2 General Medical Council: Outcomes for graduates. GMC publications, 2018. Available at: https://www.gmc-uk.org//media/documents/dc11326-outcomes-for-graduates-2018_pdf75040796.pdf

3 Taylor I, Reed MF, Kingsnorth AN, Carlson GL and Leaper DJ: Surgery in the undergraduate curriculum report by the education and professional development committee of sars. Bull Roy Coll Surg Engl 87(4): 138-139, 2005. DOI: 10.1308/147363505x39239

4 Davis CR, Toll EC, Bates AS, Cole MD and Smith FCT: Surgical and procedural skills training at medical school $-\mathrm{a}$ national review. Intl J Surgery 12(8): 877-882, 2014. PMID: 24909137. DOI: 10.1016/j.ijsu.2014.05.069

5 Tallentire VR, Smith SE, Wylde K and Cameron HS: Are medical graduates ready to face the challenges of foundation training? Postgrad Med J 87(1031): 590-595, 2011. PMID: 21690255. DOI: $10.1136 /$ pgmj.2010.115659

6 Matheson C and Matheson D: How well prepared are medical students for their first year as doctors? The views of consultants and specialist registrars in two teaching hospitals. Postgrad Med J 85(1009): 582-589, 2009. PMID: 19892893. DOI: 10.1136/ pgmj.2008.071639

7 Green R, Steven R and Haddow K: Declining applications to surgical specialist training. Bull Roy Coll Surg Engl 99(4): 142144, 2017. DOI: $10.1308 /$ rcsbull 2017.141

8 McNally SA: Surgical training: Still highly competitive but still very male. Bull Roy Coll Surg Engl 94(2): 53-55, 2012. DOI: 10.1308/147363512x13189526438675

9 Theodoulou I, Nicolaides M, Athanasiou T, Papalois A and Sideris M: Simulation-based learning strategies to teach undergraduate students basic surgical skills: A systematic review. J Surg Educ 75(5): 1374-1388, 2018. PMID: 29422405. DOI: 10.1016/j.jsurg.2018.01.013
10 Bradley P, Bond V and Bradley P: A questionnaire survey of students' perceptions of nurse tutor teaching in a clinical skills learning programme. Med Teach 28(1): 49-52, 2006. PMID: 16627324. DOI: $10.1080 / 01421590500271332$

11 Bradley P: Introducing clinical skills training in the undergraduate medical curriculum. Med Teach 24(2): 209-212, 2002. PMID: 12098445. DOI: 10.1080/014215902753549175

12 Shea BJ, Reeves BC, Wells G, Thuku M, Hamel C, Moran J, Moher D, Tugwell P, Welch V, Kristjansson E and Henry DA: Amstar 2: A critical appraisal tool for systematic reviews that include randomised or non-randomised studies of healthcare interventions, or both. BMJ 358: j4008, 2017. PMID: 28935701. DOI: $10.1136 / \mathrm{bmj} . j 4008$

13 Moher D, Liberati A, Tetzlaff J and Altman DG: Preferred reporting items for systematic reviews and meta-analyses: The prisma statement. BMJ 339: b2535-b2535, 2009. PMID: 19621072. DOI: 10.1136/bmj.b2535

14 Routt E, Mansouri Y, de Moll EH, Bernstein DM, Bernardo SG and Levitt J: Teaching the simple suture to medical students for long-term retention of skill. JAMA Dermatol 151(7): 761-765, 2015. PMID: 25785695. DOI: 10.1001/jamadermatol.2015.118

15 Wongkietkachorn A, Rhunsiri P, Boonyawong P, Lawanprasert A and Tantiphlachiva K: Tutoring trainees to suture: An alternative method for learning how to suture and a way to compensate for a lack of suturing cases. J Surg Educ 73(3): 524-528, 2016. PMID: 26907573. DOI: 10.1016/j.jsurg.2015. 12.004

16 O'Connor R, McGraw L and Killen M: A computer-based training module for suturing $\backslash[1]$ self-directed basic. Med Teacher 20(3): 203-206, 2009. DOI: 10.1080/01421599880922

17 Porte MC, Xeroulis G, Reznick RK and Dubrowski A: Verbal feedback from an expert is more effective than self-accessed feedback about motion efficiency in learning new surgical skills. Ame J Surg 193(1): 105-110, 2007. PMID: 17188099. DOI: 10.1016/j.amjsurg.2006.03.016

18 Brydges R, Carnahan $\mathrm{H}$ and Dubrowski A: Assessing suturing skills in a self-guided learning setting: Absolute symmetry error. Adv Health Sci Educ Theory Pract 14(5): 685-695, 2009. PMID: 19132540. DOI: $10.1007 / \mathrm{s} 10459-008-9151-1$

19 Xeroulis GJ, Park J, Moulton CA, Reznick RK, Leblanc V and Dubrowski A: Teaching suturing and knot-tying skills to medical students: A randomized controlled study comparing computerbased video instruction and (concurrent and summary) expert feedback. Surgery 141(4): 442-449, 2007. PMID: 17383520. DOI: $10.1016 /$ j.surg.2006.09.012

20 Summers AN, Rinehart GC, Simpson D and Redlich PN: Acquisition of surgical skills: A randomized trial of didactic, videotape, and computer-based training. Surgery 126(2): 330336, 1999. PMID: 10455902. DOI: S0039-6060(99)70173-X

21 Ganier F and de Vries P: Are instructions in video format always better than photographs when learning manual techniques? The case of learning how to do sutures. Learn Instr 44: 87-96, 2016. DOI: 10.1016/j.learninstruc.2016.03.004

22 Nousiainen M, Brydges R, Backstein D and Dubrowski A: Comparison of expert instruction and computer-based video training in teaching fundamental surgical skills to medical students. Surgery 143(4): 539-544, 2008. PMID: 18374052. DOI: $10.1016 /$ j.surg.2007.10.022

23 Wright AS, McKenzie J, Tsigonis A, Jensen AR, Figueredo EJ, Kim S and Horvath K: A structured self-directed basic skills 
curriculum results in improved technical performance in the absence of expert faculty teaching. Surgery 151(6): 808-814, 2012. PMID: 22652122. DOI: 10.1016/j.surg.2012.03.018

24 Pender C, Kiselov V, Yu Q, Mooney J, Greiffenstein P and Paige JT: All for knots: Evaluating the effectiveness of a proficiencydriven, simulation-based knot tying and suturing curriculum for medical students during their third-year surgery clerkship. Am J Surg 213(2): 362-370, 2017. PMID: 27640907. DOI: 10.1016/ j.amjsurg.2016.06.028

25 Denadai R, Oshiiwa M and Saad-Hossne R: Does bench model fidelity interfere in the acquisition of suture skills by novice medical students? AMB Rev Assoc Med Bras 58(5): 600-606, 2012. PMID: 23090233. DOI: 10.1590/s010442302012000500019

26 Bauer F, Rommel N, Kreutzer K, Weitz J, Wagenpfeil S, Gulati A, Wolff KD and Kesting MR: A novel approach to teaching surgical skills to medical students using an ex vivo animal training model. J Surg Educ 71(4): 459-465, 2014. PMID: 24776865. DOI: $10.1016 /$ j.jsurg.2014.01.017

27 Bennett SR, Morris SR and Mirza S: Medical students teaching medical students surgical skills: The benefits of peer-assisted learning. J Surg Educ 75(6): 1471-1474, 2018. PMID: 29653841. DOI: $10.1016 /$ j.jsurg.2018.03.011

28 Denadai R, Toledo AP, Oshiiwa M and Saad-Hossne R: Acquisition of suture skills during medical graduation by instructor-directed training: A randomized controlled study comparing senior medical students and faculty surgeons. Updates Surg 65(2): 131-140, 2013. PMID: 23404432. DOI: 10.1007/s13304-013-0199-y

29 Kim MJ, Boehler ML, Ketchum JK, Bueno R, Williams RG and Dunnington GL: Skills coaches as part of the educational team: A randomized controlled trial of teaching of a basic surgical skill in the laboratory setting. Am J Surg 199(1): 94-98, 2010. PMID: 20103072. DOI: 10.1016/j.amjsurg.2009.08.016

30 Denadai R, Saad-Hossne R, Oshiiwa M and Bastos EM: Training on synthetic ethylene-vinyl acetate bench model allows novice medical students to acquire suture skills. Acta Cir Bras 27(3): 271-278, 2012. PMID: 22460260. DOI: 10.1590/s010286502012000300012

31 Dubrowski A and MacRae H: Randomised, controlled study investigating the optimal instructor: Student ratios for teaching suturing skills. Med Educ 40(1): 59-63, 2006. PMID: 16441324. DOI: $10.1111 / \mathrm{j} .1365-2929.2005 .02347 . x$

32 Yap R, Moreira A, Wilkins S, Reeves F, Levinson M and McMurrick P: Suturing in small group teaching settings: A modification to peyton's four-step approach. Med Sci Educ 26(4): 575-580, 2016. DOI: 10.1007/s40670-016-0296-x

33 Martin JA, Regehr G, Reznick R, MacRae H, Murnaghan J, Hutchison $\mathrm{C}$ and Brown M: Objective structured assessment of technical skill (osats) for surgical residents. Br J Surg 84(2): 273-278, 1997. PMID: 9052454. DOI: 10.1046/j.13652168.1997.02502.x

34 Shaharan S and Neary P: Evaluation of surgical training in the era of simulation. World J Gastrointest Endosc 6(9): 436-447, 2014. PMID: 25228946. DOI: 10.4253/wjge.v6.i9.436

35 Brunt LM, Halpin VJ, Klingensmith ME, Tiemann D, Matthews BD, Spitler JA and Pierce RA: Accelerated skills preparation and assessment for senior medical students entering surgical internship. J Am Coll Surg 206(5): 897-904, 2008. PMID: 18471719. DOI: 10.1016/j.jamcollsurg.2007.12.018
36 Alameddine MB, Englesbe MJ and Waits SA: A video-based coaching intervention to improve surgical skill in fourth-year medical students. J Surg Educ 75(6): 1475-1479, 2018. PMID: 29699931. DOI: 10.1016/j.jsurg.2018.04.003

37 Bekele A, Wondimu S, Firdu N, Taye M and Tadesse A: Trends in retention and decay of basic surgical skills: Evidence from addis ababa university, ethiopia: A prospective case-control cohort study. World J Surg 43(1): 9-15, 2019. PMID: 30097707. DOI: $10.1007 / \mathrm{s} 00268-018-4752-1$

38 Gershuni V, Woodhouse J and Brunt LM: Retention of suturing and knot-tying skills in senior medical students after proficiencybased training: Results of a prospective, randomized trial. Surgery 154(4): 823-829; discussion 829-830, 2013. PMID: 24074421. DOI: $10.1016 /$ j.surg.2013.07.016

39 Fitts PM and Posner MI: Human performance. Brooks/Cole Pub. Co.: Belmont, Calif., 1967.

40 Gagné RM: Domains of learning. Interchange 3(1): 1-8, 1972. DOI: $10.1007 / \mathrm{BF} 02145939$

41 Reznick RK, Cox M, Irby DM and MacRae H: Teaching surgical skills - changes in the wind. N Engl J Med 355(25): 2664-2669, 2006. PMID: 17182991. DOI: 10.1056/NEJMra054785

42 Anastakis DJ, Regehr G, Reznick RK, Cusimano M, Murnaghan J, Brown M and Hutchison C: Assessment of technical skills transfer from the bench training model to the human model. Am J Surg 177(2): 167-170, 1999. PMID: 10204564. DOI: 10.1016/ s0002-9610(98)00327-4

43 Hammoud MM, Nuthalapaty FS, Goepfert AR, Casey PM, Emmons S, Espey EL, Kaczmarczyk JM, Katz NT, Neutens JJ, Peskin EG, Association of Professors of $\mathrm{G}$ and Obstetrics Undergraduate Medical Education C: To the point: Medical education review of the role of simulators in surgical training. Am J Obstet Gynecol 199(4): 338-343, 2008. PMID: 18639203. DOI: $10.1016 /$ j.ajog.2008.05.002

44 Lossing AG, Hatswell EM, Gilas T, Reznick RK and Smith LC: A technical-skills course for 1st-year residents in general surgery: A descriptive study. Can J Surg 35(5): 536-540, 1992. PMID: 1393871

45 Barnes RW: Surgical handicraft: Teaching and learning surgical skills. Am J Surg 153(5): 422-427, 1987. PMID: 3578661. DOI: 10.1016/0002-9610(87)90783-5

46 Jensen AR, Wright AS, Levy AE, McIntyre LK, Foy HM, Pellegrini CA, Horvath KD and Anastakis DJ: Acquiring basic surgical skills: Is a faculty mentor really needed? Am J Surg 197(1): 82-88, 2009. PMID: 19101249. DOI: 10.1016/j.amjsurg. 2008.06.039

47 Rooney DM, Hungness ES, DaRosa DA and Pugh CM: Can skills coaches be used to assess resident performance in the skills laboratory? Surgery 151(6): 796-802, 2012. PMID: 22652120. DOI: $10.1016 /$ j.surg.2012.03.016

48 Sweller J: Cognitive load during problem solving: Effects on learning. Cogn Sci 12(2): 257-285, 1988. DOI: 10.1016/03640213(88)90023-7

49 Sweller J: Cognitive load theory, learning difficulty, and instructional design. Learn Instr 4(4): 295-312, 1994. DOI: 10.1016/0959-4752(94)90003-5

50 Brunyé TT, Taylor HA and Rapp DN: Repetition and dual coding in procedural multimedia presentations. Appl Cogn Psychol 22(7): 877-895, 2008. DOI: 10.1002/acp.1396

51 Kyle Leming J, Dorman K, Brydges R, Carnahan H and Dubrowski A: Tensiometry as a measure of improvement in knot 
quality in undergraduate medical students. Adv Health Sci Educ Theory Pract 12(3): 331-344, 2006. PMID: 16847733. DOI: 10.1007/s10459-006-9005-7

52 Tsigonis AM, Jensen A, McKenzie J, Kim S and Wright AS: Validation of novel self- and expert-administered assessment tools for basic open technical skills. J Am Coll Surg 211(3): S115-S116, 2010. DOI: 10.1016/j.jamcollsurg.2010.06.305

53 Zaid H, Ward D, Sammann A, Tendick F, Topp KS and Maa J: Integrating surgical skills education into the anatomy laboratory. J Surg Res 158(1): 36-42, 2010. PMID: 19159909. DOI: 10.1016/j.jss.2008.08.012

54 Martinez A, Cassling C and Keller J: Objective structured assessment of technical skills to teach and study retention of fourth-degree laceration repair skills. J Grad Med Educ 7(1): 3235, 2015. PMID: 26217419. DOI: 10.4300/JGME-D-14-00233.1

55 Zeng W, Woodhouse J and Brunt LM: Do preclinical background and clerkship experiences impact skills performance in an accelerated internship preparation course for senior medical students? Surgery 148(4): 768-777, 2010. PMID: 20705307. DOI: 10.1016/j.surg.2010.07.022
56 Seo HS, Eom YH, Kim MK, Kim Y-M, Song BJ and Song KY: A one-day surgical-skill training course for medical students' improved surgical skills and increased interest in surgery as a career. BMC Med Educ 17(1): 1-7, 2017. PMID: 29282043. DOI: $10.1186 / \mathrm{s} 12909-017-1106-\mathrm{x}$

57 Moulton C-AE, Dubrowski A, MacRae H, Graham B, Grober E and Reznick R: Teaching surgical skills: What kind of practice makes perfect? Ann Surg 244(3): 400-409, 2006. PMID: 16926566. DOI: 10.1097/01 sla.0000234808.85789.6a

Received October 3, 2020

Revised October 24, 2020

Accepted October 28, 2020 